\title{
Adaptation of the in vitro Culture of Origanum majorana L. For Production of Phenolic Acids
}

\author{
Amany M. Korkor ${ }^{1}$, Shaza A. Mohamed ${ }^{1}$, Omaima M. Abd El-kafie ${ }^{2}$, \\ Ahmed A. Gohar ${ }^{3}$ \\ ${ }^{1}$ Pharmacognosy Department, Faculty of Pharmacy (Girls), AL-Azhar University, Egypt. \\ ${ }^{2}$ Floriculture and Medicinal Plants Department, Faculty of Agriculture, Mansoura University, Egypt. \\ ${ }^{3}$ Pharmacognosy Department, Faculty of Pharmacy, Mansoura University, 35516, Egypt.
}

\begin{abstract}
Origanum majorana L. (Lamiaceae) has a potent antioxidant activity due to its phenolic metabolites. Improving the accumulation level of the phenolic contents using plant tissue culture technique is outstanding aim. Seedlings were cultured on Murashige and Skoog (MS) medium with 6-benzyl amino purine (BAP) for shoot micro-propagation. The multiplied shoots were rooted on $M S$ medium with $0.1 \mathrm{mg} / \mathrm{L}$ indole acetic acid (IAA) to obtain axenic plantlets. Root tips were sub-cultured in MS liquid medium with naphthalene acetic acid (NAA) and indole butyric acid (IBA) to initiate adventitious root suspension culture. The highest biomass obtained from the experiment with $N A A ; 0.5 \mathrm{mg} / \mathrm{L}$ (34.4 g, fresh weight). Callus grown on media with sucrose $3 \%$, had the heaviest fresh and dry weight but the highest phenolic acids [caffeic, rosmarinic and chlorogenic acids] accumulation was with $60 \mathrm{~g} / \mathrm{L}$ sucrose (HPLC analysis). Quantification of phenolic acids content in shoots and roots of field cultivated plant, in-vitro shoots culture $(B A P, 1 \mathrm{mg} / \mathrm{L})$, in-vitro roots culture (IAA, 0.1 $\mathrm{mg} / \mathrm{L})$ and four treatments of adventitious root culture ( 0.1 and $0.5 \mathrm{NAA}, 0.1$ and $0.5 \mathrm{IBA} \mathrm{mg} / \mathrm{L})$, revealed that the sum of phenolic acids content was higher in in vitro shoot and root cultures $(4.27$ and $3.1 \mathrm{mg} / \mathrm{g}$, respectively), while the adventitious root culture grown on media supplemented with $0.5 \mathrm{mg} / \mathrm{L} \mathrm{NAA}$, resulted in the highest sum of the target phenolic acids $(45.01 \mathrm{mg} / \mathrm{g}$ ). Elicitation with $200 \mu \mathrm{M}$ methyl jasmonate (MJ) gave the highest callus biomass and the highest accumulation level of the phenolic acids, 105.82 fold of the field shoots contents.
\end{abstract}

Keywords: Caffeic acid, Chlorogenic acid, in vitro cultures, Origanum majorana L., Rosmarinic acid.

\section{Introduction}

Origanum majorana L. (sweet marjoram or knotted marjoram) is an aromatic, perennial, herbaceous plant belonging to family Lamiaceae. It grows in Mediterranean regions where it has been used from immemorial time to help people to maintain a good health [1]. O. majorana $\mathrm{L}$. has been reported as a medicinal plant and spice of commerce in the Mediterranean regions. The plant is reputed for its important pharmacological effects; cytototxic [2], antioxidant [3] and anticoagulant [4]. Phytochemicals in various extracts of $O$. majorana L. are carbohydrates, proteins, amino acids, saponins, flavonoids, phenolic compounds, vitamin $\mathrm{C}$ and tannin [5]. Essential oil content of the plant grown in Egypt ranged from 2.5-3\% [6]. The main phenolic acids (PAs) in the methanol extract of $O$. majorana L. are trans-2-hydroxycinnamic, rosmarinic, vanillic, chlorogenic, gallic and cinnamic acids whereas the main flavonoids are amentoflavone, apigenin, quercetin, luteolin, diosmetin, 5,6,3'-trihydroxy-7,8,4'- trimethoxyflavone, hesperetin, catechin and rutin [7,8].

PAs are widely spread in the plant kingdom. These metabolites show antiviral, antiseptic, antioxidant, cholagogic, immunostimulating and spasmolytic activities [9]. Rosmarinic acid (RA) has various pharmacological activities such as antimutagenic [10], cardio protective [11], antimicrobial [12], antiviral [13], analgesic and anti-inflammatory activities [14]. In addition to its effect on diabetic neuropathy [15]. Chlorogenic acid (CA) has antifungal [16], neuro-protective [17], cell immune responses [18] and hepatic glucose output effects [19]. Also, it is known to inhibit tumor cell invasion and metastasis [20]. Caffeic acid has antiulcer [21], anti-inflammatory [22] antioxidant [23] and anti-HIV [24] activities.

Modulation of the accumulation level of valuable plants secondary metabolites occurs in response to the addition of different elicitors as yeast, chitosan, methyl jasmonate (MJ), salicylic acid (SA), higher concentrations of salts and incorporation of precursors [18, 25, 26, 27].

The aim of this study was to test the ability of in vitro shoot and root cultures (organ cultures), undifferentiated callus and cell suspension cultures to accumulate rosmarinic, chlorogenic and caffeic acids. Also, to test the influence of different elicitors, precursors (phenylalanine and tyrosine), higher concentrations of salts and sucrose (4\% and 6\%) on the production level of the target PAs. 


\subsection{Initiation of the in vitro cultures:}

\section{Experimental}

\subsubsection{Surface sterilization of seeds:}

Seeds of $O$. majorana L. were washed with running water and liquid soap, immersed in $70 \%$ ethanol for $2 \mathrm{~min}$., left to dry and then immersed in 5\% sodium hypochlorite for $15 \mathrm{~min}$., then washed with sterile distilled water.

2.1.2. Germination of seeds:

The sterile seeds were transferred on MS medium; $4.4 \mathrm{~g} / \mathrm{L}$ containing $3 \%$ sucrose in $200 \mathrm{~mL}$ glass jars; $30 \mathrm{~mL} / \mathrm{jar}[28,29]$ and then incubated at $25^{\circ} \mathrm{C} \pm 2$ with $16 \mathrm{hr}$. photoperiod [30] .

\subsection{Organ in vitro cultures:}

Shoot parts of seedlings including buds (about $1 \mathrm{~cm}$ long) were used as explant for shoot cultures induction. Explant was cultured on MS medium supplemented with 0.0, 0.05, 0.1, 0.5 and $1 \mathrm{mg} / \mathrm{L}$ BAP. Shoots clusters grown on the medium supplemented with $1 \mathrm{mg} / \mathrm{L}$ BAP were divided into single shoots and transferred to fresh medium every 4 weeks. The multiplied shoots were rooted in an agar medium supplement with 0.1 $\mathrm{mg} / \mathrm{L}$ IAA to obtain axenic plantlets. Half of the plantlets were used for initiation of adventitious root culture and the other half was subjected for acclimatization.

2.2.1. Acclimatization of plantlets:

The plants were washed in sterile water several times to remove any adhering medium, subjected to hardening in autoclaved plastic pots containing hardening mixture of peat moss and vermiculite, watered with $1.1 \mathrm{~g} / \mathrm{L} \mathrm{MS}$ in distilled water and put in the green house under controlled environmental conditions for about 30 days.

2.2.2. Adventitious root culture:

Root fragments with tips ( $2 \mathrm{~cm}$ long) obtained from 3 weeks old axenic plantlets were transferred to full strength MS liquid medium $(50 \mathrm{~mL}$ in $250 \mathrm{~mL}$ flasks) with different concentrations and types of auxins; NAA $(0.1$ and $0.5 \mathrm{mg} / \mathrm{L})$ and IBA $(0.1$ and $0.5 \mathrm{mg} / \mathrm{L})$; on a rotary shaker at $100 \mathrm{rpm}$. [31,32]. Roots were subcultured every 3 weeks.

2.2.3. Induction of callus culture with different concentrations of sucrose:

Excised shoots from 30 days old sterilized plantlets were cultured in full strength media supplemented with $(3 \%, 4 \%$ and $6 \%$ ) sucrose and all the media were enriched with $2 \mathrm{mg} / \mathrm{L} 2.4-\mathrm{D}$ and $0.5 \mathrm{mg} / \mathrm{L}$ kinetin. Fresh weights of the obtained calli were recorded, calli were lyophilized and dry weights were recorded then, subjected to HPLC analysis.

2.2.4. Effect of different combinations of auxins and cytokinins on production of callus in media with $3 \%$ sucrose:

As calli grown on media supplemented with $3 \%$ sucrose gave the highest callus biomass, it was subcultured on full strength MS medium with different concentrations of phytohormones: $2 \mathrm{mg} / \mathrm{L} \mathrm{2.4-D} \mathrm{+} \mathrm{0.5}$ mg/L kin; 1 mg/L 2,4-D + 1 mg/L kin; 4 mg/L NAA + 0.4 mg/L BAP; 1 mg/L NAA + 1mg/L BAP.

2.2.5. Effect of different elicitors, salts and precursors on callus biomass and phenolic acids accumulation:

Callus previously grown on MS medium with $3 \%$ sucrose, $2 \mathrm{mg} / \mathrm{L}$ 2,4-D and $0.5 \mathrm{mg} / \mathrm{L}$ kin was inoculated on media containing the following elicitors and precursors as a feeding experiments.

2.2.5.1. Yeast extract $(50 \mathrm{~g})$ was dissolved in $200 \mathrm{~mL}$ ethanol and $50 \mathrm{~mL}$ double distilled water, after incubation for 4 days, the precipitate was collected. The process was repeated thrice and the collective precipitate was dissolved in $200 \mathrm{~mL}$ double distilled water, autoclaved then $3 \mathrm{~mL} / \mathrm{L}$ were added to freshly prepared MS medium.

2.2.5.2. MJ and SA ( $100 \mu \mathrm{M}$ or $22 \mathrm{mg} / \mathrm{L}$, respectively) were filter sterilized " $0.2 \mu \mathrm{m}$ microbial filters" and added after autoclaving, when the temperature of the medium was brought to about $40^{\circ} \mathrm{C}$.

2.2.5.3. Zinc chloride $(100 \mu \mathrm{M})$, Calcium chloride $(1.5 \mathrm{mM})$ and Copper sulphate $(50 \mu \mathrm{M})$ were used for the metal elicitation experiment.

2.2.5.4. Two concentrations of chitosan ( 200 and $500 \mathrm{ppm}$ ) were added to freshly prepared culture medium as elicitors.

2.2.5.5. Phenylalanine or tyrosine was added in concentration of (1.6 or $0.8 \mathrm{~g} / \mathrm{L}$, respectively) in separate experiments.

2.2.5.6. The effect of different concentrations of filter sterilized MJ: $50 \mu \mathrm{M}, 100 \mu \mathrm{M}$ and $200 \mu \mathrm{M}$ were studied in experiments to evaluate the growth of the culture and the phenolic acids contents. Fresh weight, dry weight and the sum of the investigated phenolic acids throughout a growth period of 5 weeks was calculated.

The calli of each experiment were collected from the culture jars, lyophilized and subjected to phytochemical analysis (HPLC). 
2.2.5.7. Induction of cell suspension culture:

About $3 \mathrm{~g}$ callus were transferred into $250 \mathrm{ml}$ flasks, $50 \mathrm{~mL}$ of fresh liquid MS medium containing filter sterilized $200 \mu \mathrm{M} \mathrm{MJ}$, the culture maintained on a rotary shaker at $100 \mathrm{rpm}$ for 3 weeks. The culture clumps were then filtered, lyophilized and then subjected to HPLC analysis. A sample from the culture medium was subjected to qualitative and quantitative analysis of the target phenolic acids.

\section{Phytochemical Analysis}

The following samples were subjected to HPLC analysis for quantitative estimation of rosmarinic, chlorogenic and caffeic acids as follows:

3.1. Shoot and root culture ( $1 \mathrm{mg} / \mathrm{L} \mathrm{BAP}, 4^{\text {th }}$ weeks of the third subculture).

3.2. In vivo roots and shoots from open field cultivated plants.

3.3. Adventitious root cultures, with different concentrations of auxins (NAA; 0.1 and $0.5 \mathrm{mg} / \mathrm{L}$ ) and (IBA; 0.1 and $0.5 \mathrm{mg} / \mathrm{L}) ; 3^{\text {rd }}$ weeks of the third subculture.

3.4. Lyophilized calli grown on MS medium supplemented with yeast, methyl jasmonate, salicylic acid, different salts, chitosan, phenylalanine and tyrosine.

3.5. Samples of calli grown on media with $50 \mu \mathrm{M}, 100 \mu \mathrm{M}$ and $200 \mu \mathrm{M} \mathrm{MJ}$ (over growth period of five weeks).

3.6. Lyophilized culture clumps from cell suspension culture (for three weeks) and a sample from the culture medium.

\section{HPLC Analysis}

Lyophilized calli (1g) were extracted three times with $30 \mathrm{ml} 50 \% \mathrm{~V} / \mathrm{V}$ methanol for $1 \mathrm{hr}$ under reflux. The combined extracts were, cooled, filtered then, diluted with methanol $(50 \% \mathrm{~V} / \mathrm{V})$ up to the volume of 100 $\mathrm{mL}$. The solution was filtered through $0.2 \mu \mathrm{m}$ filter and $10 \mu \mathrm{L}$ aliquot was analyzed adopting standard procedures [30].The phenolic acids in the methanol extracts were determined by RP HPLC using Agilent UVLC 1290 on a reversed phase column $(\mathrm{C} 18,10 \mathrm{~cm} \times 4.6 \mathrm{~mm}, 2.6 \mu \mathrm{m})$. The solvent system was a linear gradient of acetonitrile / water and phosphoric acid $\mathrm{pH}=2.2$; acetonitrile from 15 to $60 \% \mathrm{~V} / \mathrm{V}$ for $40 \mathrm{~min}$., $60 \%$ for $15 \mathrm{~min}$., from 60 to $15 \%$ and $15 \%$ for $9 \mathrm{~min}$. The flow rate was $0.8 \mathrm{~mL} / \mathrm{min}$. and the effluent was monitored by UV detection (variable wavelength detector) at $320 \mathrm{~nm}$.

\section{Statistical Analysis}

A complete randomized design was used throughout the research and the obtained data were analyzed by one-way analysis of variance (ANOVA). The means of treatments were compared using L.S.D (Least Significant Difference) test. The results were expressed as $\mathrm{mg} / \mathrm{g}$, dry weight (D.W.). The results (phenolic acids content) were reported as the mean $\pm 95 \%$ confidence interval [standard error (SE) \pm 1.96 (quantile of normal distribution for probability of $95 \%$ )] and the differences with $\mathrm{P}<0.05$ were considered to be significant [33].

\section{Results and discussion}

\subsection{Effect of different concentrations of BAP on shoots length and shoots number:}

The results in "Table 1" show the average length of shoots of $O$. majorana L. in BAP free media (7.54 $\mathrm{cm})$. The increase in the concentration of BAP was accompanied by decrease in the shoot length in all treatments and the reduction was significant when compared with control. Increasing BAP concentration increases the shoot number / explant relative to the control. It was noticed that in BAP free media the shoot production was inhibited. As a conclusion, the omission of BAP showed the highest shoot length and its incorporation increased the shoot number. These results were similar to that previously reported on Delonix regia and Cassia fistula showed that cytokinins inhibit apical dominance and stimulate axillary shoots formation [34].

Table1. The effect of different levels of BAP on the number and length of shoots of O. majorana L.:

\begin{tabular}{|c|c|c|}
\hline Concentration of BAP $(\mathbf{m g} / \mathbf{L})$ & $\begin{array}{c}\text { Shoot length }(\mathbf{c m}) \\
\text { Mean } \pm \text { SD }\end{array}$ & $\begin{array}{c}\text { Shoots number } \\
\text { Mean } \pm \text { SD }\end{array}$ \\
\hline 0.0 ( Control) & $7.54 \pm 0.29$ & $3 \pm 0.58$ \\
\hline 0.05 & $6.77 \pm 0.18$ & $7.67 \pm 0.58$ \\
\hline 0.1 & $5.45 \pm 0.095$ & $15.0 \pm 0.36$ \\
\hline 0.5 & $5.37 \pm 0.38$ & $15.99 \pm 0.69$ \\
\hline 1.0 & $4.26 \pm 0.12$ & $18.67 \pm 0.58$ \\
\hline L. S. D. at 5\% & 0.43 & 1.02 \\
\hline
\end{tabular}

L.S.D. = Least Significant Difference. $\quad$ SD = Standard Deviation. 
BAP has a marked effect on stimulating the growth of auxiliary and foliar development of shoot tip cultures [35]. Most Hybanthus enneapermus culture systems were achieved by using BAP as a supplement to basal media [36].

\subsection{Acclimatization of plantlets:}

Peatmoss and vermiculite were good hardening mixture providing the requirement of less water and good aeration for better establishment of newly generated plantlets. The experiment showed survival of 21 pots from 30 pots i.e. $70 \%$ survival frequency.

\subsection{Adventitious root cultures:}

The response of the biomass gain of adventitious root culture was higher with NAA relative to IBA. The adventitious roots $(34.37 \mathrm{~g}$, fresh wt. and $6.93 \mathrm{~g}$, dry wt.) were the greatest in rooting medium supplemented with $0.5 \mathrm{mg} / \mathrm{L} \mathrm{NAA}$, the roots were thicker and higher in number than those of roots grown in medium enriched with $0.5 \mathrm{mg} / \mathrm{L} \mathrm{IBA}(32.27 \mathrm{~g}$ and $6.2 \mathrm{~g}$, fresh and dry wt. respectively) .

\subsection{Effect of sucrose concentration on the average fresh and dry weight of callus and phenolic acids accumulation:}

Inclusion of $30 \mathrm{~g} / \mathrm{L}$ sucrose in MS medium gave the heaviest fresh weight of callus $(3.52 \mathrm{~g})$ as compared to the other sugar concentrations ( 40 and $60 \mathrm{~g} / \mathrm{L}$ ), "Table 2". Calli grown on $3 \%$ sucrose were green and friable. Increasing the carbon source inversely gained weight of the callus, as media contained $60 \mathrm{~g} / \mathrm{L}$ sucrose resulted in callus weight of $0.68 \mathrm{~g}$. Similar findings were previously reported; the optimum growth response to sucrose contents was 20-30 g/L [37].

The sum of the phenolic acids (PAs) content; rosmarinic acid, chlorogenic acid and caffeic acid (RA+ CGA+ CA) is illustrated in "Table 2". The accumulation level of PAs was inversely proportional to the biomass gain. The higher sucrose concentration (6\%) enhanced apparently the sum of PAs in calli, however it greatly affected the gain of biomass. Similar results were observed in the in vitro culture of Salvia officinalis and Eryngium planum callus cultures grown on medium contained 3\%, 4\% and $6 \%$ sucrose, where the accumulation of RA was found to be inversely related to the culture growth [38]. Higher carbohydrate content (sucrose) in the culture medium generates stress on the tissues, which may result in change in growth, cells metabolism and production of secondary metabolites, mostly in the phenylpropanoid pathway [30].

Table 2.The effect of different concentrations of sucrose on fresh and dry weights of callus cultures and phenolic acids accumulation in $O$. majorana L.:

\begin{tabular}{|c|c|c|c|c|c|c|}
\hline \multirow{2}{*}{$\begin{array}{c}\text { Sucrose } \\
\text { concentration } \\
(\mathrm{g} / \mathrm{L})\end{array}$} & \multirow{2}{*}{$\begin{array}{c}\text { Fresh } \\
\text { Weight/jar (g) } \\
\text { Mean } \pm \text { SD }\end{array}$} & \multirow{2}{*}{$\begin{array}{c}\text { Dry } \\
\text { weight/jar (g) } \\
\text { Mean } \pm \text { SD }\end{array}$} & \multicolumn{3}{|c|}{ Phenolic acids concentration(mg/g) } & \multirow{2}{*}{$\begin{array}{l}\text { Sum of phenolic } \\
\text { acids (mg/g) }\end{array}$} \\
\hline & & & $\begin{array}{c}\text { Rosmarinic acid } \\
\text { (RA) }\end{array}$ & $\begin{array}{c}\text { Chlorogenic acid } \\
\text { (CGA) }\end{array}$ & $\begin{array}{c}\text { Caffeic acid } \\
\text { (CA) }\end{array}$ & \\
\hline 30 & $3.52 \pm 0.24$ & $0.34 \pm 0.02$ & $2.5 \pm 0.14$ & $0.25 \pm 0.01$ & $0.45 \pm 0.12$ & $3.20 \pm 0.15$ \\
\hline 40 & $1.0 \pm 0.19$ & $0.23 \pm 0.33$ & $3.29 \pm 0.11$ & $0.02 \pm 0.005$ & $0.01 \pm 0.005$ & $3.32 \pm 0.15$ \\
\hline 60 & $0.68 \pm 0.06$ & $0.025 \pm 0.26$ & $3.74 \pm 0.05$ & $0.63 \pm 0.02$ & $0.2 \pm 0.01$ & $4.57 \pm 0.17$ \\
\hline L.S.D. at $5 \%$ & 0.21 & 0.28 & 0.2 & 0.25 & 0.27 & 0.24 \\
\hline
\end{tabular}

L.S.D. = Least Significant Difference.

$\mathrm{SD}=$ Standard Deviation

\subsection{Effects of different concentrations of auxins and cytokinins on the biomass production:}

Standard callus on media with 3\% sucrose and different combinations of auxins and cytokinins respond positively to the concentration of auxin as well as its type. 2,4-D was preceding to NAA. Combinaton of 2,4-D $(2 \mathrm{mg} / \mathrm{L})$ and kinetin $(0.5 \mathrm{mg} / \mathrm{L})$ gave the highest fresh and dry weight $(3.63$ and $0.34 \mathrm{~g} / \mathrm{jar})$ as shown in "Table 3".

Table 3. Effect of different types and concentrations of growth regulators on fresh and dry weights of callus cultures of $O$. majorana L.:

\begin{tabular}{|c|c|c|}
\hline $\begin{array}{c}\text { Growth regulators types and concentration in media } \\
\text { with 3\% sucrose }\end{array}$ & $\begin{array}{c}\text { Callus fresh weight callus (g) } \\
\text { Mean } \pm \text { SD }\end{array}$ & $\begin{array}{c}\text { Callus dry weight (g) } \\
\text { Mean } \pm \text { SD }\end{array}$ \\
\hline Free & $1.47 \pm 0.31$ & $0.16 \pm 0.003$ \\
\hline $2 \mathrm{mg} / \mathrm{L} 2,4-\mathrm{D}+0.5 \mathrm{mg} / \mathrm{L}$ kin. & $3.63 \pm 0.1$ & $0.34 \pm 0.01$ \\
\hline $1 \mathrm{mg} / \mathrm{L} 2,4-\mathrm{D}+1 \mathrm{mg} / \mathrm{L} \mathrm{kin}$. & $2.51 \pm 0.39$ & $0.23 \pm 0.04$ \\
\hline $4 \mathrm{mg} / \mathrm{L}$ NAA $+0.4 \mathrm{mg} / \mathrm{L} \mathrm{BAP}$ & $1.75 \pm 0.09$ & $0.16 \pm 0.004$ \\
\hline $1 \mathrm{mg} / \mathrm{L}$ NAA $+1 \mathrm{mg} / \mathrm{L} \mathrm{BAP}$ & $1.49 \pm 0.11$ & $0.14 \pm 0.007$ \\
\hline L.S.D. at 5\% & 0.25 & 0.02 \\
\hline
\end{tabular}

L.S.D. = Least Significant Difference. $\quad \mathrm{SD}=$ Standard Deviation. 


\subsection{Phenolic acids (PAs) production:}

6.6.1. Yield of PAs in the in vitro shoot and root cultures of O. majorana L.:

The concentration of PAs were estimated by HPLC analysis of the extracts of the in vitro shoot, root cultures as well as in field cultivated plant shoots and roots, results are shown in "Table 4".

Table 4.Concentrations of PAs and their sums in in vitro (shoot and root culture) and in field cultivated O. majorana L (in vivo shoots and roots):

\begin{tabular}{|c|c|c|c|c|}
\hline $\begin{array}{c}\text { Concentration of phenolic acids } \\
\text { (mg/g) }\end{array}$ & $\begin{array}{c}\text { In vitro shoot } \\
\text { culture }\end{array}$ & $\begin{array}{c}\text { In vitro root } \\
\text { culture }\end{array}$ & $\begin{array}{c}\text { Field cultivated plant } \\
\text { (in vivo shoots) }\end{array}$ & $\begin{array}{c}\text { Field cultivated plant } \\
\text { (in vivo roots) }\end{array}$ \\
\hline Rosmarinic acid (RA) & 2.16 & 1.37 & 0.158 & 0.074 \\
\hline Chlorogenic acid (CGA) & 0.81 & 0.71 & 0.045 & 0.020 \\
\hline Caffeic acid (CA) & 1.30 & 1.03 & 0.364 & 0.088 \\
\hline Sum of phenolic acids (mg/g) & 4.27 & 3.11 & 0.567 & 0.182 \\
\hline
\end{tabular}

The accumulation level of PAs in shoots of the in vitro experiment was higher than in roots and the results of the in vitro experiment was higher relative to the in vivo one. The sum of PAs increased 7.5 and 17 fold respectively. RA was apparently higher in in vitro shoot culture $(2.16 \mathrm{mg} / \mathrm{g})$ i.e. 13.7 fold and in in vitro root culture $(1.37 \mathrm{mg} / \mathrm{g})$ i.e. 18.5 fold than in the shoots $(0.16 \mathrm{mg} / \mathrm{g})$ and roots $(0.07 \mathrm{mg} / \mathrm{g})$ of the field cultivated plant (in vivo shoot and in vivo root). Similar results were obtained in Eryngium planum as it was reported that the content of RA in in vitro shoot cultures was 3.5 times higher than in the leaves of field cultivated plant [30]. Also the same results reported for Salvia officinalis in vitro shoot cultures, which showed that the levels of RA was 2.9 fold over that of the commercial samples of leaves [38].

6.6.2. Yield of PAs in adventitious root cultures grown in media supplemented with different concentrations of auxins:

Medium enriched with $0.5 \mathrm{mg} / \mathrm{L}$ NAA increased the content PAs adventitious root culture; RA, CGA, and CA; 23.45, 2.23 and 10.97 fold respectively, than those in in vitro root culture. The level of PAs in the culture responded to NAA, even at lower concentration $(0.1 \mathrm{mg} / \mathrm{L})$, than IBA $(0.5 \mathrm{mg} / \mathrm{L})$. Roots grown in medium supplemented with $0.5 \mathrm{mg} / \mathrm{L}$ NAA had higher sum of contents of the three quantified PAs by about 14.5 fold. Adventitious root in liquid culture media using NAA increased the sum of PAs contents than in in vitro shoot culture as shown in "Table 5". Similar results were reported with the adventitious root cultures of Prunella vulgaris $\mathrm{L}$., as the highest biomass gained from liquid medium containing $1 \mathrm{mg} / \mathrm{L}$ NAA and the culture grown in media enriched with $0.5 \mathrm{mg} / \mathrm{L}$ NAA accumulated higher total phenolic content [32] .

Table 5. Concentration of PAs and the biomass gain of adventitious roots in MS medium with IBA and NAA $(0.1$ and $0.5 \mathrm{mg} / \mathrm{L})$ :

\begin{tabular}{|c|c|c|c|c|}
\hline \multirow{2}{*}{$\begin{array}{l}\text { Concentration of phenolic acids } \\
(\mathrm{mg} / \mathrm{g})\end{array}$} & \multicolumn{4}{|c|}{ Auxins } \\
\hline & $0.1 \mathrm{mg} / \mathrm{L} \mathrm{IBA}$ & $0.5 \mathrm{mg} / \mathrm{L}$ IBA & $0.1 \mathrm{mg} / \mathrm{L}$ NAA & $0.5 \mathrm{mg} / \mathrm{L} \mathrm{NAA}$ \\
\hline Rosmarinic acid (RA) & 1.01 & 1.05 & 17.99 & 32.13 \\
\hline Chlorogenic acid (CGA) & 0.06 & 0.30 & 0.72 & 1.58 \\
\hline Caffeic acid (CA) & 1.30 & 1.60 & 4.92 & 11.30 \\
\hline Sum of phenolic acids (mg/g) & 2.37 & 2.95 & 23.63 & 45.01 \\
\hline \multicolumn{5}{|l|}{ Adventitious roots weight: } \\
\hline F.W./jar (g) L.S.D. at 5\% = 1.34 & $26.40 \pm 1.4$ & $32.27 \pm 0.02$ & $29.63 \pm 0.2$ & $34.37 \pm 0.15$ \\
\hline D.W./jar (g) at L.S.D. at 5\% $=0.39$ & $5.16 \pm 0.26$ & $6.20 \pm 0.26$ & $5.87 \pm 0.15$ & $6.93 \pm 0.12$ \\
\hline
\end{tabular}

\begin{tabular}{lll}
\hline F.W. = Fresh weight. & D.W. = Dry weight. & L.S.D. $=$ Least Significant Difference.
\end{tabular}

6.6.3. Effect of different elicitors and salts on callus biomass gain and PAs accumulation:

Stress factors are known to affect the accumulation level of the secondary plant metabolites in their respective in vitro cultures $[39,40]$. O. majorana $\mathrm{L}$. culture responded irregularly to the incorporation of yeasts extract, MJ, heavy metal salts, SA, and chitosan with respect to the target PAs. The effect of different additives on callus production and the level of PAs accumulation are shown in "Table 6". 
Table 6. The effect of different elicitors and salts on callus biomass and PAs accumulation in callus cultures of O. majorana L.:

\begin{tabular}{|c|c|c|c|c|c|c|c|c|c|}
\hline & \multirow{2}{*}{$\begin{array}{l}3 \% \text { Sucrose } \\
\text { (control) }\end{array}$} & \multirow{2}{*}{$\begin{array}{c}\text { Yeast } \\
\text { extract }\end{array}$} & \multirow{2}{*}{$\begin{array}{c}\text { MJ } \\
(100 \mu \mathrm{M})\end{array}$} & \multicolumn{3}{|c|}{ Salts } & \multirow{2}{*}{$\begin{array}{c}\mathrm{SA} \\
(22 \mathrm{mg} / \mathrm{L})\end{array}$} & \multicolumn{2}{|c|}{ Chitosan } \\
\hline & & & & $\begin{array}{c}\mathrm{ZnCl} 2 \\
(100 \mu \mathrm{M})\end{array}$ & $\begin{array}{c}\mathrm{CaCl} 2 \\
(1.5 \mathrm{mM})\end{array}$ & $\begin{array}{c}\text { CuSO4 } \\
(50 \mu M)\end{array}$ & & (200 ppm) & (500 ppm) \\
\hline RA (mg/g) & 2.50 & 8.39 & 16.39 & 3.74 & 3.11 & 3.85 & 5.496 & 4.650 & 6.62 \\
\hline CGA (mg/g) & 0.25 & 0.03 & 10.02 & 0.56 & 1.41 & 0.42 & 0.019 & 0.001 & 0.69 \\
\hline $\mathrm{CA}(\mathrm{mg} / \mathrm{g})$ & 0.45 & 0.01 & 3.01 & 0.29 & 0.13 & 0.09 & 0.010 & 0.001 & 0.27 \\
\hline $\begin{array}{c}\text { Sum of phenolic } \\
\text { acids }(\mathrm{mg} / \mathrm{g})\end{array}$ & 3.20 & 8.43 & 29.42 & 4.59 & 4.65 & 4.36 & 5.525 & 4.652 & 7.58 \\
\hline $\begin{array}{l}\text { D.W. } \\
\text { G.I. }\end{array}$ & $\begin{array}{c}0.34 \\
2.4\end{array}$ & $\begin{array}{c}0.56 \\
4.6\end{array}$ & $\begin{array}{l}1.97 \\
18.7\end{array}$ & $\begin{array}{c}0.36 \\
2.6\end{array}$ & $\begin{array}{l}0.33 \\
2.36\end{array}$ & $\begin{array}{c}0.14 \\
0.4\end{array}$ & $\begin{array}{c}0.33 \\
2.3\end{array}$ & $\begin{array}{c}0.43 \\
3.3\end{array}$ & $\begin{array}{c}0.29 \\
1.9\end{array}$ \\
\hline
\end{tabular}

D.W. = Callus Dry Weight

G.I. = Growth Index

6.6.3.1. Effect of yeast:

Addition of yeast extract in the culture media increased the biomass growth $(0.56$ g D.W.; G.I. $=4.6)$ and phenolic acid accumulation by 2.6 fold. Similar results were previously reported in cell suspension culture of Thalictrium rugosum and Eschscholtzia californica where yeast polysaccharide preparation induces Ltyrosine decarboxylase [41]. The activity of phenyl alanine ammonia lyase (PAL) enzyme, in cultured cells of Lythospermum erythrorhizon, after addition of yeast extract, was rapidly increased before synthesis of RA which transiently increased [42].

6.6.3.2. Effect of methyl jasmonate (MJ):

Callus culture media supplemented with $100 \mu \mathrm{M}$ MJ showed rapid response in the biomass $(1.97 \mathrm{~g}$, D.W.; G.I. = 18.7) which goes parallel with the increase in the level of accumulation of the tested PAs among all the elicited calli. Prominent increase was observed in the level of RA; 6.5 fold and also increase in the total PAs; 9.19 fold. Similar results were reported; $24 \mathrm{~h}$ after addition of $100 \mu \mathrm{M}$ MJ in cell suspension cultures of Mentha piperita the level of RA was $117.95 \mathrm{mg} / \mathrm{g}$ D.W. [43].

6.6.3.3. Effect of salicylic acid (SA):

Salicylic acid $(22 \mathrm{mg} / \mathrm{L})$ did not show any significant impact on growth of callus $(0.33 \mathrm{~g}$ D.W.; G.I. $=$ 2.3) and no prominent increase in total PAs (1.7 fold).The SA elicitation response could be attributed to the induced PAL activity that could change the phenolic levels [44].

6.6.3.4. Effect of chitosan:

Chitosan $(200 \mathrm{ppm})$ caused relative increase in callus biomass $(0.43$ g D.W.; G.I. $=3.3)$ and, at the same time, callus differentiation into shoot. This was not accompanied by prominently increased in the contents of PAs $(4.652 \mathrm{mg} / \mathrm{g}$; i.e. 1.45 fold). Biomass enhancement was inversely proportional to the increase of chitosan inclusion in the culture media; $500 \mathrm{ppm}$ caused drop in callus gain $(0.29 \mathrm{~g}$ d.w.; G.I. $=1.9)$ however, a slight increase in PAs content was recorded $(7.58 \mathrm{mg} / \mathrm{g}$ i.e. 2.3 fold). Similar results were reported with cultures of Solanum tuberosum L. and Ocimum basilicum L. [45, 46].

6.6.3.5. Effect of different salts:

6.6.3.5.1. Effect of calcium chloride and zinc chloride:

Calcium chloride, at the concentration of $1.5 \mathrm{mM}$, did not apparently increase the biomass gain $(0.336$ g D.W.; G.I. $=2.36$ ) and caused very slight increase in PAs content (1.45 fold). The calli were dark green. This result is comparable to those reported for tobacco culture [28] and soybean suspension cultures [47]. The response of the culture to the effect of zinc chloride $(100 \mu \mathrm{M})$ was not prominent $(0.36 \mathrm{~g}$, D.W.; G.I. $=2.6)$ and no increase in PAS accumulation (1.43 fold). An increase of phenolics was reported to be correlated to the increase in activity of enzymes involved in phenolic compounds metabolism, suggesting synthesis of phenolics goes under heavy metal stress. The roots of many plants exposed to heavy metals exude high levels of phenolics [48].

6.6.3.5.2. Effect of copper sulphate:

Copper sulphate $(50 \mu \mathrm{M})$ inhibited the callus growth $(0.14$ g D.W.; G.I. $=0.4)$ with no effect on PAs accumulation (1.36 fold). This might be due to inability to induce enzymes involved in biogenetic pathway of PAs or the elicitor may not be able to reach the site of action or toxic to the cells. Copper ion significantly inhibited Panax ginseng root growth in a bioreactor and resulted in an increase in protein oxidation (21\%) which was measured as carbonyl content at concentration of $50 \mathrm{M}$. In addition, $\mathrm{Cu}^{2+}$ stress resulted in increased activities of glucose-6-phosphate dehydrogenase (G6PDH), shikimate dehydrogenase (SKDH), PAL and cinnamyl alcohol dehydrogenase (CAD) [49]. The induced activities of substrate specific peroxidases (caffeic acid peroxidase, chlorogenic acid peroxidase, polyphenol oxidase and $\beta$-glucosidase) indicated that these enzymes play an important role in the synthesis of phenolic compounds. The results also provided evidence that the application of $\mathrm{Cu}^{2+}$ at 25 and $50 \mu \mathrm{M}$ was accompanied by a substantial increase in oxidative stress as 
indicated by protein oxidation and reduced root growth. The increase in phenolic compounds related enzymes clearly reflects the protective response to cellular damage induced by higher levels of $\mathrm{Cu}^{2+}$.

6.6.4. Effect of L- phenylalanine and L- tyrosine on PAs accumulation:

L- Phenylalanine increased the biomass gain than did L- tyrosine. This was accompanied by relative increase in the PAs synthesis. Total PAs content increased in response to L- phenyl alanine by 3.89 fold, while L- tyrosine increased it by 2.83 fold. RA yield was 8.95 and $9.078 \mathrm{mg} / \mathrm{g} \mathrm{D.W}$. for L- phenylalanine and Ltyrosine, respectively. Enhancement of a secondary metabolite like RA might be due to stimulation of key enzyme (PAL) activity which is the gate way of shikimic acid pathway [30]. Previous studies demonstrated that actively growing tissue converted more than $20 \%$ of supplied L- phenylalanine and L- tyrosine to the caffeoyl ester and this high rate of synthesis conceded with an increase in the activity of PAL enzyme which in turn produced RA [50].

6.6.5. Effect of different concentrations of MJ on PAs accumulation:

The results in "Table 7" show the level of PAs production and biomass gain over growth period of 5 weeks. PAs production goes parallel to MJ concentration as well as age of the culture; $200 \mu \mathrm{M}$ MJ in the callus culture media gave the highest PAs and biomass production and the maximum level was in the fifth week. That is to say; PAs production by the incorporation of $\mathrm{MJ}$ in the medium is concentration and culture age dependent. "Fig. 1, 2 and 3" illustrate the growth curves, in which it is clear that the rate of growth in all treatments was in an increasing manner in relation to time and began to be almost constant after the $4^{\text {th }}$ week; deceleration phase.

Table7. The effect of different concentrations of MJ on PAs accumulation, average callus fresh and dry weight (F.W. and D.W.) of O. majorana L.:

\begin{tabular}{|c|c|c|c|c|c|c|c|c|c|c|}
\hline \multirow{2}{*}{$\begin{array}{c}\text { MU } \\
\text { concentration } \\
\text { (iM) }\end{array}$} & \multicolumn{2}{|c|}{$1^{\text {tw week }}$} & \multicolumn{2}{|c|}{$2^{\text {sd }}$ week } & \multicolumn{2}{|c|}{$3^{\text {nd }}$ week } & \multicolumn{2}{|c|}{$4^{\text {th }}$ week } & \multicolumn{2}{|c|}{ sth week } \\
\hline & $\begin{array}{l}\text { Phesolic } \\
\text { acids } \\
\text { content } \\
\text { (mg/g) }\end{array}$ & $\begin{array}{l}\text { Callus } \\
\text { F.W/ D.W } \\
\text { (e) }\end{array}$ & $\begin{array}{c}\text { Phenolic } \\
\text { acids } \\
\text { content } \\
(\mathrm{mg} / \mathrm{g})\end{array}$ & $\begin{array}{c}\text { callus } \\
\text { F.W/ D.W } \\
\text { (g) }\end{array}$ & $\begin{array}{l}\text { Phenolic } \\
\text { acids } \\
\text { content } \\
\text { (mg/g) }\end{array}$ & $\begin{array}{l}\text { Callus } \\
\text { F.W/ D.W } \\
\text { (g) }\end{array}$ & $\begin{array}{l}\text { Phenolic } \\
\text { acids } \\
\text { content } \\
\text { (mg/g) }\end{array}$ & $\begin{array}{l}\text { Callus } \\
\text { F.W/ D.W } \\
\text { (q) }\end{array}$ & $\begin{array}{l}\text { Phenolic } \\
\text { acids } \\
\text { content } \\
\text { (mgig) }\end{array}$ & $\begin{array}{c}\text { Callus } \\
\text { E.W/D.W } \\
\text { (g) }\end{array}$ \\
\hline $50 \mathrm{\mu M}$ & 9.32 & $1.01 / 0.12$ & 16.89 & $1.61 / 0.19$ & 18.20 & $195 / 0.23$ & 22.45 & $2.25 / 0.26$ & 32.25 & $2.35,0.27$ \\
\hline $100 \mu \mathrm{M}$ & 12.68 & 1.0170 .12 & 17.77 & $1.76 / 0.21$ & 24.79 & 2.087025 & 2996 & $237 / 0.28$ & 35.30 & 2.3670 .28 \\
\hline $200 \mu \mathrm{M}$ & 14.12 & $1.02<0.12$ & 17.94 & $2.04 / 0.24$ & 28.69 & $2.51 / 0.30$ & 42.00 & $2 . 8 5 \longdiv { 0 . 3 4 }$ & 60.00 & $299 / 0.35$ \\
\hline
\end{tabular}

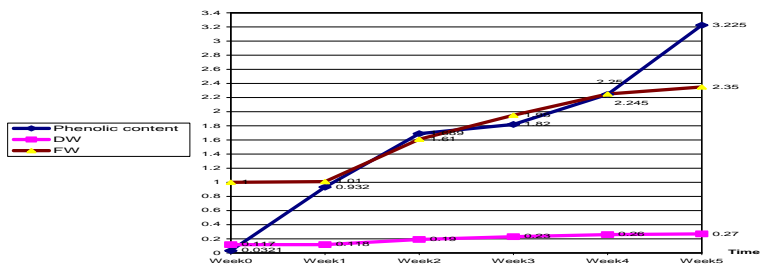

Fig. 1: Growth curve showing the relation between PAs content, average fresh and dry weight of callus culture of $O$. majorana L. grown on MS medium containing $50 \mu \mathrm{M}$ MJ during a growth period.

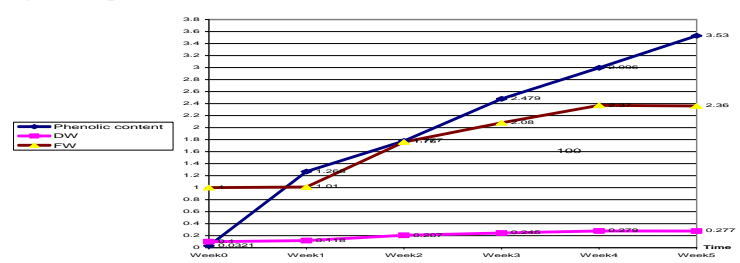

Fig. 2: Growth curve showing the relation between PAs content, average fresh and dry weight of callus culture of $O$. majorana L. grown on MS medium containing $100 \mu \mathrm{M}$ MJ during a growth period.

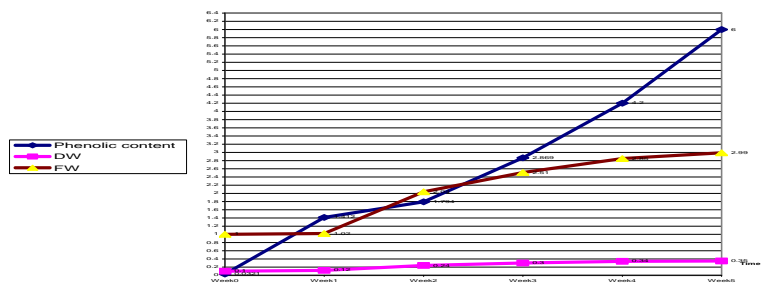

Fig.3: Growth curve showing the relation between PAs contents, average fresh and dry weight of callus culture of $O$. majorana L. grown on MS medium containing $200 \mu \mathrm{M}$ MJ during a growth period.

N.B: The values representing the PAs contents are divided by 10 to facilitate its representation on the growth curve. 
6.6.6. Callus growth and phenolic acids yield in cell suspension culture of $O$. majorana L.:

For testing suitability of our results for fermentation as a tool for biotechnological production, it was inevitable to induce suspension culture. Calli clumps grown on liquid MS media supplemented with 3\% sucrose and $200 \mu \mathrm{M} \mathrm{MJ}$ were friable and suitable to provide acceptable cells to start cell suspension culture. The growth of the cells was prominent and seemed to show linear growth time relation. Measuring the cell mass weight after three week period, the biomass was found to increase from $3 \mathrm{~g}$ to $5.22 \mathrm{~g}$. The total PAs content estimated in lyophilized clumps collected from cell suspension culture containing $3 \%$ sucrose and $200 \mu \mathrm{M} \mathrm{MJ}$, after three weeks of growth, was $14.45 \mathrm{mg} / \mathrm{g}$ (i.e. 4.5 fold increase compared with cells grown in control media; no MJ). HPLC analysis of the culture medium showed that none of the investigated PAs is excreted out the cells.

\section{Conclusion}

The in vitro systems could be regarded as an alternative way to obtain valuable compounds with important pharmacological activities. For shoot multiplication of $O$. majorana $\mathrm{L}$. on media with different concentrations of BAP, the concentration of $1 \mathrm{mg} / \mathrm{L}$ gave the highest number of shoots; which rooted on fresh media containing $0.1 \mathrm{mg} / \mathrm{L}$ IAA and acclimatized to give the highest sum of the target PAs (RA, CGA and CA) in in vitro shoots and roots among other experiments. On induction of adventitious root culture that grown in media supplemented with $0.5 \mathrm{mg} / \mathrm{L}$ NAA, it resulted in adventitious roots with the highest sum of the target PAs. The medium containing 3\% sucrose, $2 \mathrm{mg} / \mathrm{L} 2,4-\mathrm{D}$ and $0.5 \mathrm{mg} / \mathrm{L} \mathrm{kin}$. was suitable to produce the greatest callus biomass that could be used for elicitation and precursor feeding experiments. Culture elicitation with 200 $\mu \mathrm{M}$ MJ gave the highest accumulation of the target PAs.

\section{References}

[1]. D.N. Deshmane, C.H. Gadgoli and G.V. Halade, Anticonvulsant effect of Origanum majorana L., Pharmacology, 1, 2007 , 64-78.

[2]. S. Rao, B. Timsina and V. K. Nadumane, Evaluation of the anticancer potentials of Origanum marjorana on fibrosarcoma (HT1080) cell line, Asian Pac. J. Trop. Dis., 4(1), 2014, S389-S394.

[3]. R. Erenler, O. Sen, H. Aksit, I. Demirtas, A.S. Yaglioglu, M. Elmastas and I. Telci, Isolation and identification of chemical constituents from Origanum majorana and investigation of antiproliferative and antioxidant activities, J. Sci. Food Agric., 96 (3), 2015, 822-836.

[4]. R. Yazdanparast and L. Shahriyary, Comparative effects of Artemisia cunculus, Satureja hortensis and Origanum majorana on inhibition of platelet adhesion, aggregation and secretion. Vas. Pharmacol., 48(1), 2008, 32-37.

[5]. P.A. Mathew and M.N. Padmanabhan, Quality control profiling, antifungal and in vivo cytotoxic potential of Origanum majorana L., Int. J. Pharm. Bio. Sci., 6 (2), 2015, 634-640.

[6]. F.M. Soliman, M.F. Yousif, S.S. Zaghloul and M.M. Okba, Seasonal variation in the essential oil composition of Origanum majorana L. cultivated in Egypt, Z. Naturforsch C, 64, 2009, 611 - 614.

[7]. I. H. Sellami, E. Maamouri, T. Chahed, W. A. Wannes, M. E. Kchouk and B. Marzouk, Effect of growth stage on the content and composition of the essential oil and phenolic fraction of sweet marjoram (Origanum majorana L.), Industrial Crops and Products, 30, 2009, 395-402.

[8]. O. Baatour, R. Kaddour, H. Mahmoudi, L. Tarchoun, I. Bettaieb, N. Nasri, S. Mrah, G. Hamdaoui, M. Lachaal and B. Marzouk, Salt effects on Origanum majorana fatty acids and essential oil composition, J. Sci. Food Agric., 91, 2011, $2613-2620$.

[9]. S. Khadem and R.J. Marles, Monocyclic phenolic acids; hydroxy- and polyhydroxybenzoic acids: occurrence and recent bioactivity studies, Molecules, 15, 2010, 7985-8005.

[10]. H. Ozturk, H. Ozturk, E.H. Terzi, U. Ozgen, A. Duran and I. Uygun, Protective effects of rosmarinic acid against renal ischaemia/reperfusion injury in rats, J. Pak. Med. Assoc., 64 (3), 2014, 260-265.

[11]. D. Karthik, P. Viswanathan and C.V. Anuradha, Administration of rosmarinic acid reduces cardiopathology and blood pressure through inhibition of $\mathrm{p} 22$ phox NADPH oxidase in fructose-fed hypertensive rats, J. Cardiovasc. Pharmacol., $58,2011,514-521$.

[12]. A. Abedini, V. Roumy, S. Mahieux, M. Biabiany, A. Standaert-Vitse, C. Riviere, S. Sahpaz, F. Bailleul, C. Neut and T. Hennebellwe, Rosmarinic acid and its methyl ester as antimicrobial components of the hydromethanolic extract of Hyptis atrorubens Poit. (Lamiaceae), Evidence-based Complementary and Alternative Medicine, 2013, 2013, 1-11.

[13]. M. Dubois, F. Bailly, G. Mbemba, J.F. Mouscadet, Z. Debyser and M. Witvrouw, Reaction of rosmarinic acid with nitrite ions in acidic conditions: discovery of nitro- and dinitrorosmarinic acids as new anti-HIV-1 agents, J. Med. Chem. 51, 2008, 2575-2579.

[14]. N.D. Stansbury, Rosmarinic acid as a novel agent in the treatment of allergies and asthma, Journal of Restorative Medicine, 3(1), 2014, 121-126.

[15]. P. Hasanein and M.L. Zaheri, Effects of rosmarinic acid on an experimental model of painful diabetic neuropathy in rats, Pharm. Biol., 15, 2014, 1-5.

[16]. W.S. Sung and D.G. Lee, Antifungal action of chlorogenic acid against pathogenic fungi, mediated by membrane disruption, Pure and Appl. Chem., 82(1), 2010, 219-226.

[17]. E.H. Ahn, D.W. Kim, M.J. Shin, S.W. Kwon, Y.N. Kim, D.S. Kim, S.S. Lim, J. Kim, J. Park, W.S. Eum, H.S. Hwang and S.Y. Choi, Chlorogenic acid improves neuroprotective effect of PEP-1-ribosomal protein S3 against ischemic insult, Exp. Neurobiol., 20 (4), 2011, 169-175.

[18]. F. Abraham, A. Bhatt, C.L. Keng, G. Indrayanto and F. Shaida, Effect of yeast extract and chitosan on shoot proliferation, morphology and antioxidant activity of Curcuma mangga in vitro plantlets, African Journal of Biotechnology, 10 (40), 2011, 77877795 .

[19]. H. Hemmerle, H.J. Burger, G. Schubert, R. Peter, W. Schindler, E. Paulus and A.W. Herling, Chlorogenic acid and synthetic chlorogenic acid derivatives: Novel inhibitors of hepatic glucose-6-phosphate translocase, J. Med. Chem., 40 (2), $1997,137-145$.

[20]. U.H. Jin, J.Y. Lee, S.K. Kang, J.K. Kim, W.H. Park, J.G. Kim, S.K. Moon and C.H. Kim, A phenolic compound, 5-caffeoylquinic acid (chlorogenic acid), is a new type and strong matrix metalloproteinase-9 inhibitor: isolation and identification from methanol extract of Euonymus alatus, Life Sci., 77(22), 2005, 2760-2769. 
[21]. M.P. Barros, M. Lemos, E.L. Maistro, M.F. Leite, J.P. Sousa, J.K. Bastos and S.F. Andrade, Evaluation of antiulcer activity of the main phenolic acids found in Brazilian green propolis, J Ethnopharmacol., 120 (3), 2008, 372-377.

[22]. P. Michaluart, J. L. Masferrer, A. M. Carothers, K. Subbaramaiah, B. S. Zweifel, C. Koboldt, J. R. Mestre, D. Grunberger, P. G. Sacks, T. Tanabe and A. J. Dannenberg, Inhibitory effects of caffeic acid phenethyl ester on the activity and expression of cyclooxygenase-2 in human oral epithelial cells and in a rat model of inflammation, Cancer Res., 59(10), 1999,2347-2352.

[23]. Y. Sato, S. Itagaki, T. Kurokawa, J. Ogura, M. Kobayashi, T. Hirano, M. Sugawara and K. Iseki, In vitro and in vivo antioxidant properties of chlorogenic acid and caffeic acid, Int. J. Pharm. 403, 2011, 136-138.

[24]. S. Z. Huang, X. J. Zhang, X. Y. Li, H. Z. Jiang, Q. Y. Ma, P. C. Wang, Y. Q. Liu, J. M. Hu, Y. T. Zheng, J. Zhou and Y. X. Zhao, Phenols with anti-HIV activity from Daphne acutiloba, Planta Med.,78(2) , 2012 ,182-185.

[25]. Z. Cai, A. Kastell and I. Smetanska, Chitosan or yeast extract enhance the accumulation of eight phenolic acids in cell suspension cultures of Mallus domestica Borkh, Journal of Horticultural Science and Biotechnology, 89 (1), 2014, 93-99.

[26]. H. Riedel, D.N. Akumo, N.M.M.T. Saw, O. Kutuk, P. Neubauer and I. Smetanska, Elicitation and precursor feeding influence phenolic acids composition in Vitis vinifera suspension culture, African Journal of Biotechnology, 11(12), $2012,3000-3008$.

[27]. D. Gonzalez-mendoza, D. Cervantes-Garcia, R. Troncoso-Roja and O. Grimaldo-Juarez, Production of phenolics and flavonoids compounds in Euglena gracilis under copper stress, Journal of Pure and Applied Microbiology, 7(1), 2013, 93-100.

[28]. T. Murashige and F. Skoog, A revised medium for rapid growth and bioassays with tobacco tissue cultures, Physiologia plantarum, 15(43), 1962, 473-497.

[29]. Y. Hussein, G. Amin, E. Hashem and K. Youssef, In vitro cultivation of marjoram (Origanum majorana L.) under influence of 2,4D (2,4-Dichlorophenoxy Acetic Acid) as herbicide, Life Science Journal, 11(2), 2014, 249-257.

[30]. M. Kikowska, J. Budzianowski, A. Krawczyk and M. Thiem, Accumulation of rosmarinic, chlorogenic and caffeic acids in in vitro cultures of Eryngium planum L., Acta Physiol. Plant., 34, 2012, 2425-2433.

[31]. M. Kikowska, B. Thiem, E. Sliwinska, M. Rewers, M. Kowalczyk, A. Stochmal and W. Oleszek, The Effect of nutritional factors and plant growth regulators on micropropagation and production of phenolic acids and saponins from plantlets and adventitious root cultures of Eryngium maritimum L., Journal of Plant Growth Regulation, 33, 2014 , 809-819.

[32]. H. Fazal, B.H. Abbasi and A. Nisar, Optimization of adventitious root culture for production of biomass and secondary metabolites in Prunella vulgaris L., Applied Biochemistry and Biotechnology, 174 (6), 2014, 2086-2095.

[33]. K.A. Gomez and A.A. Gomez, Statistical procedures for the agricultural research (John Wiley and Sons; Int. Rice Res. Inst. Book, USA, 2 Ed., 1984).

[34]. O.M. Abd El-Kafie, Physiological studies on some ornamental plants, Ph.D. Thesis, Fac. of Agric., Mansoura Univ., Egypt, 1988.

[35]. J.N. Buah, E. Danso, K.J. Taah, E.A. Abole, E.A. Bediako, J. Asiedu and R. Baidoo, The effects of different concentration cytokinins on the in vitro multiplication of plantain (Musa sp.), Biotechnology, 9 (3), 2010, 343-347.

[36]. D.K. Patel, R. Kumar, M. Kumar, K. Sairam and S. Hemalatha, Evaluation of in vitro aldose reductase inhibitory potential of different fraction of Hybanthus enneaspermus Linn F. Muell, Asian Pac. J. Trop. Biomed., 2 (2), 2012,134-139.

[37]. J. Zhao, L.C. Davis and R. Verpoorte, Elicitor signal transduction leading to production of plant secondary metabolites, Biotechnol. Adv., 23(4), 2005, 283-333.

[38]. P.C. Santos-Gomes, R.M. Seabra, P.B. Andrade and M. Fereira, Phenolic antioxidant compounds produced by in vitro shoots of sage (Salvia Officinalis L.), Plant Sci., 162(6), 2002, 981-987.

[39]. O. Cakir and S. Ari, Defensive and secondary metabolism in Astragalus chrysochlorus cell cultures in response to yeast extract stressor, Journal of Environmental Biology, 30(1), 2009, 51-55.

[40]. A. Ramakrishna and G.A. Ravishankar, Influence of abiotic stress signals on secondary metabolites in plants, Plant Signaling and Behavior, 6(11), 2011, 1720-1731.

[41]. I.A. Marques and Brodelius, P.E., Elicitor-induced L-tyrosine decarboxylase from plant cell suspension cultures. I. Induction and purification, Plant Physiol., 88, 1992, 46-51.

[42]. H. Mizukami, T. Ogawa, H. Ohashi and B.E. Ellis, Induction of rosmarinic acid biosynthesis in Lithospermum erythrorhizon cell suspension cultures by yeast extract, Plant Cell Rep., (9), 1992, 480-483.

[43]. J. Krzyzanowska, A. Czubacka, L. Pecio, M. Przybys and T. Doroszewska, The effects of jasmonic acid and methyl jasmonate on rosmarinic acid production in Mentha piperita cell suspension cultures, Plant Cell Tiss. Organ Cult., 108, $2012,73-81$.

[44]. R. Campos, H. Nonogaki, T. Suslow and M.E. Saltveit, Isolation and characterization of a wound inducible phenylalanine ammonia-lyase gene (LsPAL1) from Romaine lettuce leaves, Physiol. Plant., 121, 2004, 429-438.

[45]. R. Asghari-Zakaria, B. Maleki-Zanjani and E. Sedgh, Effect of in vitro chitosan application on growth and minituber yield of Solanum tuberosum L., Plant, Soil and Environment, 55 (6), 2009 , 252-256.

[46]. H.J. Kim, F. Chen, X. Wang and N.C. Rajapakse, Effect of chitosan on the biological properties of sweet basil (Ocimum basilicum L.), Agric. Food Chem., 53 (9), 2005, 3696-3701.

[47]. O.L. Gamborg, R.A. Miller and K. Ojima, Nutrient requirements of suspension cultures soybean root cells, Exp. Cell Res., 50, 1968, $148-151$.

[48]. B. Winkel-Shirley, Biosynthesis of flavonoids and effects of stress, Curr. Opin. Plant Biol., 5(3), $2002,218-223$.

[49]. M. Ali, K.W. Yu, E.J. Hahn and K.Y. Paek, Methyl jasmonate and salicylic acid elicitation induces ginsenosides accumulation, enzymatic and non-enzymatic antioxidant in suspension culture Panax ginseng roots in bioreactors, Plant Cell Rep., 25, 2006, 613620 .

[50]. A. Razzaque and B.E. Ellis, Rosmarinic acid production in Coleus cell cultures, Planta, 137, 1977, 287 -291. 